\title{
KAJIAN POTENSI DAN KENDALA DALAM PROSES USAHATANI DAN PEMASARAN MANGGA DI KABUPATEN INDRAMAYU
}

\author{
Elly Rasmikayati ${ }^{1}$, Gema Wibawa ${ }^{1}$, Rani Andriani ${ }^{1}$, Sri Fatimah ${ }^{1}$, dan Bobby Rachmat Saefudin ${ }^{2}$ \\ ${ }^{1}$ Fakultas Pertanian, Universitas Padjadjaran \\ ${ }^{2}$ Peneliti dan Staf Pusat Riset Pangan Berkelanjutan DRPMI Universitas Padjadjaran \\ E-mail: e.rasmikayati@unpad.ac.id
}

\begin{abstract}
ABSTRAK, Mangga merupakan salah satu buah favorit yang selalu dicari oleh konsumen namun sulit didapatkan di pasar. Padahal, respon konsumen terhadap buah mangga adalah peluang bisnis yang dapat dimaksimalkan oleh petani mangga terutama di Kabupaten Indramayu sebagai sentra produksi mangga terbesar di Jawa Barat. Tujuan dari penelitian ini adalah mendeskripsikan dan menganalisis karakteristik proses usahatani dan pemasaran mangga di Kabupaten Indramayu dan juga menjelaskan kendala dan potensi dalam memenuhi ketersediaan mangga sepanjang tahun. Survey dilakukan di Kabupaten Indramayu sebagai salah satu sentra produksi mangga di Jawa Barat terhadap 130 petani yang dipilih menggunakan teknik sampling acak sederhana. Data dianalisis menggunakan alat analisis kuantitatif descriptive statistics analysis dan Chi-Square yang dipadukan dengan analisis data kualitatif berupa wawancara dengan para responden. Penelitian ini menemukan bahwa proporsi petani yang penguasaan pohon mangganya terbatas adalah $56 \%$ sedangkan sisanya $44 \%$ adalah petani mangga yang jumlah pohonnya lebih banyak. Petani yang kepemilikan pohon mangganya terbatas cenderung mengusahakan mangga dengan seadanya, sebaliknya petani yang jumlah penguasaan pohonnya besar cenderung lebih serius dan intensif baik dalam proses usahatani mangga maupun dalam segi pemasaran mangganya. Potensi yg dapat menjadi modal pengembangan usahatani mangga dan pemasaran mangga adalah pengalaman bertani mangga dan kemudahan pinjaman modal, terutama dari perbankan, sehingga sangat berpotensi bagi para petani untuk dapat meningkatkan meningkatkan kontinuitas produktvitas dan kualitas mangganya. Sedangkan kendala yang terjadi adalah akses pinjaman modal untuk petani kecil yang relatif masih sulit, faktor curah hujan yang tinggi, biaya pemeliharaan yang semakin mahal, dan masih terbatasnya industri pengolahan mangga di Indramayu.
\end{abstract}

Kata kunci: Agribisnis mangga; pengusaan pohon mangga; petani mangga; proses usahatani dan pemasaran mangga

\section{THE POTENTIAL AND CONSTRAINTS OF MANGO'S FARMING AND MARKETING PROCESS IN INDRAMAYU REGENCY}

\begin{abstract}
Mangoes are one of the most popular fruits favored by consumers. However, mangoes are rarely found in the market. The consumer response to mango fruit should be a potential business opportunity for mango farmers in Indramayu District as the largest mango production center in West Java. This research aimed at describing and analyzing the characteristics of the farming and marketing process of mango in Indramayu District and describing the constraints and potentials to fulfill the availability of mangoes throughout the years. A survey was conducted to 130 mango farmers in Indramayu Regency who were selected using cluster sampling technique. The data was analyzed using quantitative methods, descriptive statistics and Chi-Square analysis, combined with qualitative data analysis of the interview with respondents. The findings revealed that $56 \%$ of the farmers had limited number of mango trees and the remaining $44 \%$ had more trees. Farmers with more mango trees tended to put more effort both in the process of mango farming and marketing. There were some factors that were potentials for the development of mango farming and marketing to increase the continuity of productivity and quality of mangoes such as the farmers' experience and the ease acces of funding, particularly from banks. In addition, the constraints encountered were limited access to capital loans for small farmers, high rainfall, expensive maintenance costs and limited number of mango processing industry in Indramayu.
\end{abstract}

Keywords: Mango agribusiness; mangga tree preparation; mango farmer; farming process and mango marketing

\section{PENDAHULUAN}

Di Indonesia terdapat beberapa provinsi yang menjadi sentra produksi mangga nasional. Salah satu sentra produksi mangga bagi nasional adalah Provinsi Jawa Barat. Terdapat beberapa daerah di Jawa Barat yang merupakan sentra produksi mangga diantaranya yaitu Kabupaten Indramayu, Kabupaten Cirebon, Kabupaten Majalengka, Kabupaten Kuningan, dan Kabupaten Sumedang. Data produksi mangga Jawa Barat ditampilkan dalam Tabel 1.

Sebagai sentra produksi mangga terbesar di Jawa Barat, Indramayu dijuluki sebagai Kota Mangga, hal tersebut menjadi produk unggulan tersendiri bagi Kabupaten Indramayu. Wilayah ini identik dengan buah mangga karena setiap halaman rumah, tempat sekolah, rumah ibadah, perkantoran, taman di Kabupaten Indramayu mayoritas ditanami pohon mangga, selain itu kebunkebun mangga setiap desa terbentang luas dibeberapa lokasi diwilayah Indramayu. Tanaman mangga sangat cocok tumbuh dan berbuah di Kabupaten Indramayu, hal tersebut terjadi karena faktor struktur tanah, iklim, dan topografi yang mendukung sehingga buah mangga yang berasal dari Indramayu memiliki ciri khas rasa yang enak, manis, dan aroma wangi yang tajam.

Tanaman mangga sangat cocok dibudidayakan di Kabupaten Indramayu sehingga dapat memberikan keuntungan yang lebih tinggi dibandingkan dengan budidaya tanaman lainnya. Dari sisi permintaan konsumen, mangga merupakan salah satu buah yang 
paling banyak disukai dan selalu dicari oleh konsumen. Dari dalam negeri, tentunya jumlah permintaannya sangat besar karena merupakan refreksi dari jumlah produksi mangga nasional yang tidak diekspor ditambah dengan impor mangga. Kemudian dari sisi permintaan mangga dari luar negeri, walau secara trend ekspor mangga tersebut telah menggambarkan kenaikan yang pesat dan memiliki kontribusi yang besar pada total ekspor hortikultura, namun kenaikan tersebut belum menggambarkan kenaikan ekspor yang stabil dan signifikan dibandingkan dengan perkembangan pada tingkat produksi. Persentase ekspor mangga terhadap jumlah produksi hanya berada di kisaran 0,05\% saja (BPS, 2016). Penyebab utama masih kecilnya persentase ekspor mangga tersebut adalah masih rendahnya kualitas produk mangga yang dihasilkan petani sehingga tidak memenuhi standar ekspor.

Tabel 1. Produksi Mangga di Wilayah Sentra Mangga Jawa Barat

\begin{tabular}{lrrrrrr}
\hline \multirow{2}{*}{ Kabupaten } & \multicolumn{5}{c}{ Tahun } & $\begin{array}{c}\text { Share } \\
(\%)\end{array}$ \\
\cline { 2 - 6 } & 2012 & 2013 & 2014 & 2015 & 2016 & \multicolumn{1}{c}{ (\%) } \\
\hline Indramayu & 6.851 & 8.479 & 7.244 & 6.874 & 9.064 & 25 \\
Cirebon & 6.205 & 3.095 & 5.166 & 3.744 & 3.109 & 14 \\
Majalengka & 4.852 & 1.024 & 5.717 & 6.440 & 3.753 & 14 \\
Kuningan & 3.938 & 3.241 & 2.333 & 3.211 & 1.292 & 9 \\
Sumedang & 2.901 & 2.361 & 2.063 & 2.349 & 2.340 & 8 \\
$\quad$ Jumlah & 24.747 & 18.200 & 22.523 & 22.618 & 19.558 & 70 \\
Jawa Barat & 34.221 & 32.707 & 32.148 & 31.337 & 26.011 & 100 \\
\hline Keterangan: Share adalah rasio total produksi kabupaten dengan total \\
\multicolumn{5}{c}{ produksi Jawa Barat }
\end{tabular}

Sumber: Sumber: Jawa Barat dalam Angka 2013, 2014, 2015, 2016, dan 2017 (diolah).

Berdasarkan Tabel 1, Kabupaten Indramayu sebagai sentra produksi utama di Jawa Barat yang menjadikan mangga sebagai identitas daerahnya tersebut menghasilkan jumlah produksi mangga yang berfluktuasi. Menurut Dinas Pertanian Tanaman Pangan Provinsi Jawa Barat (2016) Dalam kurun waktu 5 tahun, Kabupaten Indramayu mencapai produksi mangga terbanyak pada tahun 2016 dengan jumlah 9.064 ton sedangkan tahun 2012 hanya mencapai 6.851 ton. Hal serupa juga dialami oleh keempat kabupaten lainnya, yang mana produksi mangga di masingmasing kabupaten tersebut mengalami peningkatan dan penurunan jumlah yang sangat signifikan. Pada tahun 2012, Kabupaten Cirebon dan Kuningan mampu memproduksi mangga sebanyak 6.205 ton dan 3.938 ton. Namun, jumlah tersebut berkurang hampir mencapai 50\% di tahun 2016 sehingga produksinya menjadi 3.109 ton dan 1.292 ton. Begitupun dengan Kabupaten Majalengka yang mengalami jumlah produksi mangga yang berfluktuasi dan signifikan. Jumlah produksi mangga di Kabupaten Sumedang cenderung stabil dari tahun 2012 - 2016 yaitu dengan rata-rata produksi 2.403 ton setiap tahunnya. Kabupaten Indramayu, Cirebon, Majalengka, Kuningan, dan Sumedang memberikan kontribusi rata-rata dalam 5 tahun sebesar 25\%; 14\%; 14\%; 9\%; dan 8\% terhadap total produksi mangga di Jawa Barat.
Melihat kesenjangan yang terjadi di tingkat konsumen dan produsen mangga bahwa mangga merupakan salah satu buah yang paling banyak disukai dan selalu dicari oleh konsumen. Tetapi seringkali konsumen kecewa, karena mangga seringkali kualitasnya tidak terjaga dan sering tidak tersedia di pasar. Pertanyaan yang kemudian muncul adalah bagaimana proses usahatani mangga dan pemasaran yang dilakukan oleh petani mangga. Dengan demikian sangat menarik untuk meneliti bagaimana sebenarnya sistem usahatani mangga dan pemasarannya di Kabupaten Indramayu. Tujuan dari penelitian ini adalah: 1) mendeskripsikan dan menganalisis karakteristik proses usahatani dan pemasarannya pada petani mangga di Kabupaten Indramayu; dan 2) menjelaskan kendala dan potensi dalam memenuhi ketersediaan mangga sepanjang tahun.

\section{METODE}

Penelitian dilakukan dengan metode Survey-eksplanatory, dengan pengambilan sampel multi-stage random sampling. Tahapannya adalah memilih satu kecamatan yang merupakan sentra mangga di Kabupaten Indramayu, dan dengan bantuan perangkat lunak Microsoft excel 2013 terpilihlah kecamatan Cikedung secara acak. Selanjutnya memilih desa sentra mangga secara acak dan terpilihlah desa Jatisura. Sedemikian sehingga responden petani terpilih secara random sebanyak 130 responden.

Desain penelitian yang digunakan adalah mix method dimana desain penelitian ini menggabungkan desain penelitian kuantitatif dan kualitatif untuk memperdalam hasil yang didapat (Creswell and Clark. 2008). Penelitian ini akan membahas lebih banyak variabel di dalam hal proses usahatani dan proses pemasaran dari hasil penelitian dari Sulistyowati dan Natawidjaja (2016) yang mengungkapkan tentang pola tanam mangga (proses usahatani) dan tingkat komersialisasi petani (proses pemasaran mangga) di Jawa Barat. Variabelvariabel proses usahatani yang dianalisis dalam penelitian ini diantaranya: Jumlah Kepemilikan Pohon Mangga, Sumber Modal Usahatani, Lokasi Menanam Mangga, Pola Tanam Mangga, Kepemilikan Saprotan, Sumber Air untuk Pemeliharaan Mangga, Pengendalian OPT, Penggunaan Teknologi Off Season. Sedangkan variablevariabel proses pemasaran diantaranya adalah: Tujuan Pasar Petani, Penentu Harga Jual, Sistem Pembayaran, Akses Informasi Harga Pasar, Kondisi Jalan ke Lokasi Kebun Mangga, dan Kemitraan Mangga.

Untuk mendeskripsikan dan menganalisis karakteristik proses usahatani dan pemasarannya serta menjelaskan kendala dan potensi dalam memenuhi ketersediaan mangga sepanjang digunakan alat analisis kuantitatif descriptive statistics analysis, dan analisis Chi-Square yang dipadukan dengan analisis data kualitatif dari hasil wawancara dengan para responden. 


\section{HASIL DAN PEMBAHASAN}

\section{Karakteristik Kepemilikan Pohon Mangga}

Petani mangga dibagi menjadi dua kelompok berdasarkan jumlah pohon yang kuasainya, yaitu petani yang jumlah pohonnya terbatas dan banyak. Petani yang jumlah pohonnya terbatas adalah petani yang menguasai paling banyak 60 pohon mangga, sedangkan petani yang jumlah pohonnya banyak adalah petani yang menguasai lebih dari 60 pohon mangga. Kriteria ini merupakan adaptasi dari Hartanto (1984). Hasil kajian sebagaimana tersaji pada Tabel 2, menunjukkan bahwa proporsi petani yang penguasaan pohon mangganya terbatas adalah $56 \%$ sedangkan sisanya 44\% adalah petani mangga yang jumlah pohonnya lebih banyak. Petani yang pohonnya terbatas jumlahnya sedikit lebih banyak dari pada petani yang pohonnya banyak. Karakteristik kemilikan pohon mangga di di Kabupaten Indramayu ini sejalan dengan penelitian mangga di tingkat Jawa Barat dari penelitian Rasmikayati dkk (2017) bahwa petani kecil lebih banyak dari petani sedang dan besar.

Tabel 2. Karakteristik Petani Mangga di Indramayu Berdasarkan Kepemilikan Pohon Mangga

\begin{tabular}{|c|c|c|}
\hline $\begin{array}{c}\text { Kepemilikan Pohon } \\
\text { Mangga }\end{array}$ & Frequency & Percent \\
\hline Terbatas & 73 & 56.2 \\
\hline Banyak & 57 & 43.8 \\
\hline Total & 130 & 100.0 \\
\hline
\end{tabular}

Sumber: Data Primer, diolah 2018

\section{Analisis Karakteristik Proses Usahatani Mangga di Kab. Indramayu}

Hasil analisis menunjukkan bahwa dari segi proses usahatani, petani yang kepemilikan pohon mangganya terbatas cenderung mengusahakan mangga dengan seadanya, sebaliknya petani yang jumlah penguasaan pohonnya besar, usahatani yang mereka lakukan lebih serius dan intensif.

Hal ini terlihat dari beberapa variabel diantaranya dalam hal sumber modal usahatani mangga. Nilai sigifikansi uji Chi-Square nya bernilai 0,001 yang berarti ada keterkaitan antara kepemilikan pohon mangga dengan sumber modal petani. Petani yang jumlah pohonnya terbatas lebih mengandalkan modal sendiri dari pada yang jumlah pohonnya banyak. Hasil yang sama diungkapkan oleh penelitian Sulistyowati dan Natawidjaja (2016) bahwa Petani mangga lebih banyak menggunakan sumber pembiayaan yang berasal dari modal sendiri. Petani yang jumlah pohonnnya banyak mempunyai akses yang lebih baik terhadap pinjaman bank untuk menambah dan meningkatkan kualitas dan kuantitas produksi mangganya. Kemudian dilihat dari lokasi menaman pohon mangga, Nilai sigifikansi uji Chi-Square nya bernilai 0,032 yang berarti ada keterkaitan antara kepemilikan pohon mangga dengan lokasi menanam mangga. Petani yang jumlah pohonnya terbatas lebih dominan menanam mangga di halaman rumahnya, sedangkan petani yang jumlah pohonnnya banyak terlihat sudah lebih berani untuk menanam mangga tidak hanya di halaman rumahnya saja tetapi juga di ladang/kebun dan sawah mereka. Kemudian dari segi pola tanam mangga, nilai sigifikansi uji Chi-Square nya bernilai 0,176 yang berarti bahwa tidak ada keterkaitan antara kepemilikan pohon mangga dengan pola tanam mangga. Dalam Tabel 2 terlihat bahwa persentase jumlah petani yang menerapkan pola tanam polikultur dan yang monokultur hampir sama.

Dalam segi kepemilikan sarana dan prasarana pertanian, nilai sigifikansi uji Chi-Square nya bernilai 0,082 yang berarti ada keterkaitan antara kepemilikan pohon mangga dengan kepemilikan saprotan. Petani yang jumlah pohonnya terbatas masih banyak yang tidak memilikinya, mereka lebih megandalkan untuk menyewa, sedangkan petani yang jumlah pohonnnya banyak sudah banyak yang mampu membeli saprotan. Kemudian berdasarkan sumber air yang digunakan, nilai sigifikansi uji Chi-Square nya bernilai 0,000 yang berarti ada keterkaitan antara kepemilikan pohon mangga dengan sumber irigasi. Petani yang jumlah pohonnya banyak sudah banyak menerapkan beberapa sumber irigasi seperti menggabungkan sumur bor dan embung, sedangkan pada petani yang jumlah pohonnya terbatas lebih banyak yang masih mengandalkan air hujan sebagai sumber pengairan utama usahatani mangganya.

Kemudian dalam sistem pengendalian hama dan OPT, nilai sigifikansi uji Chi-Square nya bernilai 0,017 yang berarti ada keterkaitan antara kepemilikan pohon mangga dengan sistem pengendalian hama dan OPT yang dilakukan petani. Terlihat bahwa petani dengan jumlah pohon mangga terbatas lebih banyak yang belum menerapkan sistem pengendalian hama dan OPT dari pada petani dengan jumlah pohon banyak. Selain itu, diantara petani dengan jumlah pohon banyak sudah ada yang mengunakan sistem perangkap hama secara penuh tanpa menggunakan pestisida sama sekali.

Sementara itu dalam hal penggunaan teknologi off season yang diterapkan, kedua kelompok petani ini relatif mempunyai kesamaan, yaitu sama-sama sudah banyak yang menggunakan teknologi off season dengan total mencapai $89 \%$ petani mangga di kab. Indramayu. Kemudian sekitar $52 \%$ petani di Indramayu baik yang jumlah pohonnya terbatas maupun banyak, keduanya sama-sama sudah banyak yang menerapkan pola tanam mangga secara khusus / monokultur. Hal ini dikarenakan karena mangga merupakan tanaman musiman yang waktu musimnnya singkat, oleh karena itu untuk memenuhi permintaan konsumen dibutuhkan teknologi pembuangaan/off season (Natawidjaja et. al., 2014).

\section{Analisis Karakteristik Proses Pemasaran Mangga di Kab. Indramayu}

Hasil analisis menunjukkan bahwa dari segi proses pemasaran mangga, petani yang kepemilikan pohon mangganya terbatas cenderung lebih baik dari pada petani 
Tabel 3. Proses Usahatani Mangga Dikaitkan dengan Kepemilikan Pohon Mangga Petani di Indramayu

\begin{tabular}{|c|c|c|c|c|c|c|}
\hline \multirow{3}{*}{ Variabel Proses Usahatani Mangga } & \multicolumn{6}{|c|}{ Kepemilikan Pohon Mangga } \\
\hline & \multicolumn{2}{|c|}{ Terbatas } & \multicolumn{2}{|c|}{ Banyak } & \multicolumn{2}{|c|}{ Total } \\
\hline & $\begin{array}{c}\text { Frek. } \\
\text { (orang) }\end{array}$ & Persen $(\%)$ & $\begin{array}{c}\text { Frek. } \\
\text { (orang) }\end{array}$ & Persen $(\%)$ & $\begin{array}{c}\text { Frek. } \\
\text { (orang) }\end{array}$ & Persen $(\%)$ \\
\hline \multicolumn{7}{|l|}{ Sumber Modal Usahatani Mangga } \\
\hline 1) Modal Sendiri & 58 & 79,5 & 39 & 68,4 & 97 & 73,9 \\
\hline 2) Pinjaman Bank & 8 & 11,0 & 16 & 28,1 & 24 & 19,5 \\
\hline 3) Pinjaman Mitra & 7 & 9,6 & 2 & 3,5 & 9 & 6,5 \\
\hline Total & 73 & 100,0 & 57 & 100,0 & 130 & 100,0 \\
\hline Pearson Chi-Square (Sig.) & \multicolumn{6}{|c|}{$0,001 * * *$} \\
\hline \multicolumn{7}{|l|}{ Lokasi Menanam Pohon Mangga } \\
\hline 1) Halaman Rumah & 9 & 12,3 & 4 & 7,0 & 13 & 9,7 \\
\hline 2) Halaman Rumah dan Kebun/Ladang & 29 & 39,7 & 16 & 28,1 & 45 & 33,9 \\
\hline 3) Halaman rumah, Kebun/Ladang, dan Sawah & 4 & 5,5 & 8 & 14,0 & 12 & 9,8 \\
\hline 4) Kebun/Ladang & 29 & 39,7 & 25 & 43,9 & 54 & 41,8 \\
\hline 5) Kebun/Ladang dan Sawah & 2 & 2,7 & 4 & 7,0 & 6 & 4,9 \\
\hline Total & 73 & 100,0 & 57 & 100,0 & 130 & 100,0 \\
\hline Pearson Chi-Square (Sig.) & \multicolumn{6}{|c|}{$0,032 * *$} \\
\hline \multicolumn{7}{|l|}{ Pola Tanam Mangga } \\
\hline 1) Monokultur & 38 & 52,1 & 29 & 51 & 67 & 51,5 \\
\hline 2) Polikultur & 35 & 47,9 & 28 & 49 & 63 & 48,5 \\
\hline Total & 73 & 100,0 & 57 & 100,0 & 130 & 100,0 \\
\hline Pearson Chi-Square (Sig.) & \multicolumn{6}{|c|}{0,176} \\
\hline \multicolumn{7}{|l|}{ Kepemilikan Saprotan } \\
\hline 1) Beli & 61 & 83,6 & 55 & 96,5 & 116 & 90,0 \\
\hline 2) Beli dan Sewa & 1 & 1,4 & 1 & 1,8 & 2 & 1,6 \\
\hline 3) Sewa & 1 & 1,4 & 0 & 0 & 1 & 0,7 \\
\hline 4) Tidak Punya & 10 & 13,7 & 1 & 1,8 & 11 & 7,7 \\
\hline Total & 73 & 100,0 & 57 & 100,0 & 130 & 100,0 \\
\hline Pearson Chi-Square (Sig.) & \multicolumn{6}{|c|}{$0,082 *$} \\
\hline \multicolumn{7}{|l|}{ Sumber Air untuk Pemeliharaan Mangga } \\
\hline 1) Embung & 10 & 13,7 & 5 & 8,8 & 15 & 11,2 \\
\hline 2) Hujan & 20 & 27,4 & 6 & 10,5 & 26 & 19,0 \\
\hline 3) Sumur Bor & 30 & 41,1 & 19 & 33,3 & 49 & 37,2 \\
\hline 4) Sumur Bor dan Embung & 11 & 15,1 & 27 & 47,3 & 38 & 31,2 \\
\hline 5) Sumur Bor dan Irigasi & 2 & 2,7 & 0 & 0,0 & 2 & 1,4 \\
\hline Total & 73 & 100,0 & 57 & 100,0 & 130 & 88,8 \\
\hline Pearson Chi-Square (Sig.) & \multicolumn{6}{|c|}{$0,000 * * *$} \\
\hline \multicolumn{7}{|l|}{ Pengendalian OPT } \\
\hline 1) Menggunakan Perangkap Hama & 0 & 0,0 & 1 & 1,8 & 1 & 1,8 \\
\hline 2) Menggunakan Pestisida & 49 & 67,1 & 49 & 86,0 & 98 & 76,5 \\
\hline 3) Menggunakan Pestisida dan perangkap hama & 4 & 5,5 & 1 & 1,8 & 5 & 3,6 \\
\hline 4) Tidak Menggunakan & 20 & 27,4 & 6 & 10,5 & 26 & 19,0 \\
\hline Total & 73 & 100,0 & 57 & 100,0 & 130 & 100,0 \\
\hline Pearson Chi-Square (Sig.) & \multicolumn{6}{|c|}{$0,017 * *$} \\
\hline \multicolumn{7}{|l|}{ Penggunaan Teknologi Off Season } \\
\hline 1) Tidak & 12 & 16,4 & 3 & 5 & 15 & 10,9 \\
\hline 2) $\mathrm{Ya}$ & 61 & 83,6 & 54 & 95 & 115 & 89,1 \\
\hline Total & 73 & 100,0 & 57 & 100,0 & 130 & 100,0 \\
\hline Pearson Chi-Square (Sig.) & \multicolumn{6}{|c|}{0,179} \\
\hline
\end{tabular}

Ket : ***: Signifikan dengan taraf nyata $1 \%$

** : Signifikan dengan taraf nyata $5 \%$

* : Signifikan dengan taraf nyata $10 \%$

Sumber : Data Primer, diolah 2017

yang jumlah pohon mangganya terbatas. Hal ini terlihat dari beberapa variabel diantaranya tujuan pasar mangga. Nilai sigifikansi uji Chi-Square nya bernilai 0,000 yang berarti ada keterkaitan antara kepemilikan pohon mangga dengan Tujuan Pasar. Petani yang jumlah pohon mangganya sudah lebih banyak yang menjual mangganya secara langsung ke pabrik atau ke kios-kios mangga atau langsung ke pasar tradisional. Berbeda dengan petani yang jumlah pohon mangganya terbatas yang masih mengandalkan tengkulak dalam pemasaran mangganya. Tujuan pasar petani mangga yang jumlah pohonnya terbatas di Kabupaten Indramayu ini sejalan dengan Penelitian Widyarina dkk. (2017) di Kabupaten Majalengka bahwa tujuan pasar mayoritas responden petani mangga di Kabupaten Majalengka 
adalah menjual hasil produk mangganya ke pedagang pengumpul/tengkulak. Kemudian selain itu, petani mangga cenderung menjualnya ke bandar/pedagang besar/supplier. Menurut petani, menjual hasil panen mangga ke pedagang pengumpul/tengkulak sangatlah mudah dan dekat. Petani mangga masih banyak yang memiliki prinsip bahwa rezeki haruslah dibagikan kepada sesama, terutama sesama warga sekitar. Maka dari itu petani mangga lebih cenderung menjual buah mangga mereka ke tengkulak di sekitar lingkungan rumah mereka.

Kemudian dilihat dari sistem pembayaran, nilai sigifikansi uji Chi-Square nya bernilai 0,000 yang berarti tidak ada keterkaitan antara kepemilikan pohon mangga dengan sistem pembayaran. Namun demikian, petani dengan jumlah pohon banyak yang menggunakan sistem pembayaran jatuh tempo. Hal ini merupakan akibat dari penjualan secara langsung ke pabrik, toko atau ke pasar tradisional. Sedangkan petani dengan jumlah pohon mangga terbatas kebanyakan menerapkan sistem pembayaran tunai karena mereka menjual mangga kepada tengkulak. Kemudian jika ditinjau berdasarkan akses petani terhadap informasi harga pasar terlihat bahwa $48 \%$ petani dengan kepemilikan pohon mangga terbatas tidak mempunyai akses terhadap informasi harga pasar. Sedangkan petani dengan jumlah pohon mangga banyak $86 \%$ dari mereka sudah mendapatkannya dari berbagai sumber seperti, pembeli di pasar, internet, mitra dan lain-lain. Menurut penelitian Ramadhani dan Rasmikayati (2017), tujuan pemasaran mayoritas adalah ke pedagang pengumpul/tengkulak dipilih karena adanya faktor kemudahan akses, kedekatan/keluarga, sistem pembayaran tunai, dan pinjaman saprotan.

\section{Potensi dan Kendala yang Dihadapi Petani di Kab. Indramayu}

Sudah kurang lebih 10 tahun terakhir usahatani mangga di Kabupaten Indramayu, mengalami peningkatan, baik dari segi produksi, luas lahan, maupun jumlah pohonnya. Petani selalu melakukan kegiatan budidaya mangga yang terdiri atas penyiapan lahan, penanaman, pemupukan, penyiangan, pengendalian HPT, pemanenan dan pemangkasan. Bahkan dilakukan penanaman pohon-pohon baru apabila pohon mangga yang mereka miliki sudah tidak produktif. Petani mangga lebih bergantung pada penggunaan zat perangsang tumbuh daripada budidaya tanaman mangga secara alami karena permintaan akan komoditas mangga selalu terjadi setiap saat. Dalam satu tahun panen dapat mencapai 3 sampai 4 kali. Bulan Agustus sampai september merupakan periode yang paling tinggi produksinya. Namun demikian menurut

Tabel 4. Proses Pemasaran Mangga Dikaitkan dengan Kepemilikan Pohon Mangga Petani di Indramayu

\begin{tabular}{|c|c|c|c|c|c|c|}
\hline \multirow{3}{*}{ Variabel Proses Pemasaran Mangga } & \multicolumn{6}{|c|}{ Kepemilikan Pohon Mangga } \\
\hline & \multicolumn{2}{|c|}{ Terbatas } & \multicolumn{2}{|c|}{ Banyak } & \multicolumn{2}{|c|}{ Total } \\
\hline & $\begin{array}{l}\text { Frek. } \\
\text { (orang) }\end{array}$ & Persen $(\%)$ & $\begin{array}{l}\text { Frek. } \\
\text { (orang) }\end{array}$ & Persen $(\%)$ & $\begin{array}{l}\text { Frek. } \\
\text { (orang) }\end{array}$ & Persen $(\%)$ \\
\hline \multicolumn{7}{|l|}{ Tujuan Pasar Mangga } \\
\hline 1) Kios dan pabrik & 1 & 1.4 & 24 & 42.1 & 25 & 21.7 \\
\hline $\begin{array}{l}\text { 2) Langsung Dijual ke Bandar/Pedagang Besar/ } \\
\text { Supplier }\end{array}$ & 6 & 8.2 & 6 & 10.5 & 12 & 9.4 \\
\hline 3) Langsung Dijual ke Pasar Tradisional & 1 & 1.4 & 22 & 38.6 & 23 & 20.0 \\
\hline $\begin{array}{l}\text { 4) Melalui Perantara Pedagang Pengumpul/ } \\
\text { Tengkulak }\end{array}$ & 36 & 49.3 & 1 & 1.8 & 37 & 25.5 \\
\hline 5) Pengontrak & 29 & 39.7 & 4 & 7.0 & 33 & 23.4 \\
\hline Total & 73 & 100.0 & 57 & 100.0 & 130 & 100.0 \\
\hline Pearson Chi-Square (Sig.) & \multicolumn{6}{|c|}{$0,000 * * *$} \\
\hline \multicolumn{7}{|l|}{ Penentu Harga Jual } \\
\hline 1) Keputusan Bersama & 11 & 15.1 & 6 & 10.5 & 17 & 12.8 \\
\hline 2) Pembeli & 57 & 78.1 & 50 & 87.7 & 107 & 82.9 \\
\hline 3) Petani & 5 & 6.8 & 1 & 1.8 & 6 & 4.3 \\
\hline Total & 73 & 100.0 & 57 & 100.0 & 130 & 100.0 \\
\hline Pearson Chi-Square (Sig.) & \multicolumn{6}{|c|}{0,423} \\
\hline \multicolumn{7}{|l|}{ Sistem Pembayaran } \\
\hline 1) Jatuh Tempo & 4 & 5.5 & 3 & 5.3 & 7 & 5.4 \\
\hline 2) Tunai & 67 & 91.8 & 32 & 56.1 & 99 & 74.0 \\
\hline 3) Tunai dan Jatuh Tempo & 2 & 2.7 & 22 & 38.6 & 24 & 20.7 \\
\hline Total & 73 & 100.0 & 57 & 100.0 & 130 & 100.0 \\
\hline Pearson Chi-Square (Sig.) & \multicolumn{6}{|c|}{$0,000 * * *$} \\
\hline \multicolumn{7}{|l|}{ Akses Petani terhadap Informasi Harga Pasar } \\
\hline 1) Tidak & 48 & 65.8 & 8 & 14 & 56 & 39.9 \\
\hline 2) $\mathrm{Ya}$ & 25 & 34.2 & 49 & 86 & 74 & 60.1 \\
\hline Total & 73 & 100.0 & 57 & 100.0 & 130 & 100.0 \\
\hline Pearson Chi-Square (Sig.) & \multicolumn{6}{|c|}{$0,000 * * *$} \\
\hline \multicolumn{7}{|l|}{ Ket : *** : Signifikan dengan taraf nyata $1 \%$} \\
\hline $\begin{array}{l}* * \quad \text { Signifikan dengan taraf nyata } 5 \% \\
* \quad: \text { Signifikan dengan taraf nyata } 10 \%\end{array}$ & & & & & & \\
\hline
\end{tabular}

Sumber : Data Primer, diolah 2017 
Rasmikayati dan Saefudin (2018) untuk teknik budidaya di tingkat petani masih kurang yaitu dalam pemeliharaan, penanganan hama dan penyakit, dan pemakaian ZPT yang tidak bijaksana. Permasalahan lain yaitu karena kurangnya pengetahuan petani dan hanya memikirkan keuntungan.

Bantuan dari pemerintah untuk usahatani mangga tidak begitu sering terjadi, hanya pada tahun 2013 terdapat bantuan bibit dari pemerintah dan kemudian disusul oleh penyuluhan pada tahun 2014. Namun penyuluhan dan pelatihan belum sering yang khusus tentang usahatani mangga. Bantuan dan penyuluhan atau pelatihan mayoritas yang diberikan masih tentang usahatani padi. Hal ini disinyalir karena petani Indramayu dianggap sudah mandiri dalam hal budidaya mangga dan pemasarannya sudah terjamin melalui peran tenkulak dan bandar sekitar.

Meskipunsudahmandiri, tidaksedikit petanimangga yang memilih mengontrakkan atau memborongkan pohon mangga mereka ke tengkulak. Hal ini dikarenakan semakin banyaknya tengkulak yang ada dan biasanya lebih menawarkan untuk membeli mangga petani dengan cara dikontrak atau diborong saja. Biasanya, akibat butuh uang dalam waktu cepat dan menghindari harga anjlok pada saat panen raya maka petani mangga lebih memilih mengontrakkan atau memborongkan pohon mangganya. Selain itu, sulitnya modal juga menjadi pertimbangan petani mangga untuk langsung mengontrakkan atau memborongkan pohon mangganya, karena jika harus dipanen sendiri berarti harus dilakukan pemeliharaan yang cukup intensif agar hasilnya banyak. Sistem yang dilakukan biasanya kontrak hanya selama 1 tahun saja, tapi apabila petani sedang butuh uang maka kotrak bisa diperpanjang selama 5 tahun. Menurut Sulistyowati dkk. (2013) masalah lain yang sering di keluhkan petani dalam bermitra adalah masalah pembayaran. Petani mitra merasa jatuh tempo pembayaran yang telalu lama, yaitu hingga 3 bulan terhitung sejak barang di kirim. Beberapa permasalahan pokok yang dihadapi oleh petani dalam menjalankan kemitraan antara lain adalah: (1) masih lemahnya pengetahuan petani tentang pascapanen; (2) lemahnya akses terhadap informasi pasar; (3) lemahnya permodalan dan (4) lemahnya infrastruktur penanganan pascapanen dan mutu. Pembentukan kelompok tani (poktan) dan gabungan kelompok tani (gapoktan) mangga bisa menjadi solusi untuk meningkatkan daya tawar petani sehingga nilai jual produknya akan meningkat. Menurut Safe'i dkk (2018), tergabungkanya petani sebagai anggota gapoktan dapat meningkatkan pendapatan petani.

Meskipun pohon mangga di Kab. Indramayu selalu berbuah, namun ada kalanya juga mengalami penurunan produksi, namun tidak terlalu signifikan. Cuaca dan HPT menjadi salah satu faktor yang menyebabkan hal itu terjadi. Bahkan menurut penuturan beberapa responden petani mangga ada pohon mangga yang tidak berbuah sama sekali pada tahun 2015. Kendala cuaca yang dihadapi adalah ketika banyak angin dan hujan pada saat pohon mangga tengah berbunga, sehingga mengakibatkan bunga mudah rontok. Akibatnya peyemprotan akan dilakukan terus menerus. Selain itu jika musim hujan, serangan penyakit akan lebih banyak seperti timbulnya jamur pada buah sehingga buah akan lebih cepat membusuk serta buah yang dihasilkan tidak mulus. Faktor teknologi penanganan hama ini merupakan faktor yang berpengaruh nyata mendorong peningkatan perilaku agribisnis petani mangga ke arah yang positif dan pada akhirnya dapat meningkatkan daya saing dan kesejahteraan petani mangga itu sendiri (Rasmikayati dan Saefudin, 2018).

Untuk permodalan, petani-petani besar atau petani yang kepemilikan pohon mangganya banyak tidak terlalu sulit mendapatkannya, bahkan mereka seringkali ditawari secara langsung oleh lembaga kredit seperti bank dan KUR untuk meminjam modal. Namun hal tersebut berbeda bagi petani-petani kecil, mereka masih kesulitan untuk mengaksesnya sehingga permodalan menjadi hambatan. Masalah permodalan ini juga seringkali menjadi faktor sangat penting karena bisa menjadi penyebab terikatnya petani mangga dalam sistem yang tidak menguntungkan mereka. Hal ini karena yang juga harus diperhitingkan selama menunggu panen mangga adalah biaya-biaya konsumtif keluarga petani mangga, terutama untuk para petani yang menjadikan bertani mangga sebagai pekerjaan pokoknya. Hal ini sejalan dengan hasil penelitian Khaswarina (2017) bahwa dari aspek pengeluaran, faktor yang dominan adalah jumlah anggota rumah tangga, tabungan, jumlah anak sekolah, konsumsi non pangan dan pendapatan total. Faktor yang responsif mempengaruhi pengeluaran adalah pendapatan total.

Salah satu harapan dari petani mangga adalah semakin banyaknya industri pengolahan mangga. Karena meskipun dijuluki sebagai Kota Mangga, masih jarang ditemui industri pengolahan mangga. Menurutnya dengan adanya industri pengolahan tersebut semakin membuat Indramayu layak mendapat julukan sebagai Kota Mangga yang bisa dijadikan sebagai City Branding untuk menarik minat wisatawan untuk berkunjung ke Kabupaten Indramayu.

\section{SIMPULAN}

Proporsi petani yang penguasaan pohon mangganya terbatas adalah $56 \%$ sedangkan sisanya $44 \%$ adalah petani mangga yang jumlah pohonnya lebih banyak. Petani yang kepemilikan pohon mangganya terbatas cenderung mengusahakan mangga dengan seadanya, sebaliknya petani yang jumlah penguasaan pohonnya besar, usaha tani yang mereka lakukan lebih serius dan intensif baik dalam proses usahatani mangga yang mereka lakukan maupun dalam segi pemasaran mangganya. Hal ini terlihat dari beberapa variabel usahatani mangga yaitu Sumber Modal Usahatani, Lokasi Menanam Mangga, Kepemilikan Saprotan, Sumber Air untuk Pemeliharaan Mangga, dan Pengendalian OPT dan variabel pemasaran mangga yaitu Tujuan Pasar Petani, Sistem Pembayaran, 
dan Akses Informasi Harga Pasar. Potensi yang dimiliki petani mangga di Kab. Indramayu selain dari sudah berpengalaman dalam hal budidaya mangga juga dalam hal permodalan, petani-petani besar atau petani yang kepemilikan pohon mangganya banyak tidak terlalu sulit mendapatkannya, bahkan mereka seringkali ditawari secara langsung oleh lembaga kredit seperti bank dan KUR untuk meminjam modal. Namun hal tersebut berbeda bagi petani-petani kecil, mereka masih kesulitan untuk mengaksesnya sehingga permodalan menjadi kendala bagi petani kecil. Salah satu harapan dari petani mangga sendiri adalah semakin banyaknya industri pengolahan mangga yang akan semakin membuat Indramayu layak mendapat julukan sebagai Kota Mangga yang bisa dijadikan sebagai City Branding untuk menarik minat wisatawan untuk berkunjung ke Kabupaten Indramayu.

\section{UCAPAN TERIMAKASIH}

Terima kasih kepada Kemenristek Dikti yang telah membiayai penelitian ini dalam skema PUPT (Penelitian Unggulan Perguruan Tinggi) tahun anggaran 2017.

\section{DAFTAR PUSTAKA}

Creswell, J.W. \& Clark, V.L.P. (2008). Designing and Conducting Mixed Methods Research. London: Sage Publications.

Dinas Pertanian Tanaman Pangan Provinsi Jawa Barat. (2016). Produksi Buah Mangga. Jawa Barat.

Hartanto. (1984). Petani Kecil dan Karakteristiknya. Jakarta: CV. Yasaguna

Khaswarina, S. (2017). Faktor Dominan Yang Mempengaruhi Ekonomi Rumah Tangga Petani Karet Di Desa Koto Damai Kabupaten Kampar. Sosiohumaniora, 19, (3), 199-205

Natawidjaja, R.S., Rum, I.A., Sulistyowati, L., \& Saidah, Z. (2014). Improving The Participation Of Smallholder Mango Farmers In Modern Retail Channels In Indonesia. The International Review of Retail, Distribution And Consumer Research, 24, (5), 564-580.
Ramadhani, W. \& Rasmikayati, E. (2017). Pemilihan Pasar Petani Mangga Serta Dinamika Agribisnisnya Di Kecamatan Panyingkiran Kabupaten Majalengka Provinsi Jawa Barat. Mimbar Agribisnis: Jurnal Pemikiran Masyarakat Ilmiah Berwawasan Agribisnis, 3, (2), 185-205.

Rasmikayati, E., \& Saefudin, B. R. (2018). Analisis FaktorFaktor Yang Mampu Mendorong Petani Mangga Untuk Meningkatkan Perilaku Agribisnisnya Pada Era Globalisasi. Paradigma Agribisnis, 1, (1), $1-13$.

Rasmikayati, E. \& Saefudin, B.R. (2018). Confirmatory Factor Analysis: Faktor-Faktor Penentu Agribisnis Mangga Di Kabupaten Majalengka Berdasarkan Penguasaan Lahannya. Jurnal Agribisnis Terpadu, 4, (1).

Rasmikayati, E., Sulistyowati, L., \& Saefudin, B. R. (2017). Risiko Produksi Dan Pemasaran Terhadap Pendapatan Petani Mangga: Kelompok Mana Yang Paling Berisiko. Mimbar Agribisnis: Jurnal Pemikiran Masyarakat Ilmiah Berwawasan Agribisnis, 3, (2), 105-116.

Safe'i, R., Febryano, I.G., \& Aminah, L.N. (2018). Pengaruh Keberadaan Gapoktan Terhadap Pendapatan Petani Dan Perubahan Tutupan Lahan Di Hutan Kemasyarakatan. Sosiohumaniora, 20, (2), 109-114.

Statistik, B.P. (2015). Jawa Barat Dalam Angka. Badan Pusat Statistik Provinsi Jawa Barat. (Pada 10 Juli 2018).

Statistik, B.P. (2017). Jawa Barat Dalam Angka. Badan Pusat Statistik Provinsi Jawa Barat. Diambil dari https://www.bps.go.id.

Sulistyowati, L., Natawidjaja, R. \& Saidah, Z. (2013). Faktor-Faktor Sosial Ekonomi Yang Mempenaruhi Keputusan Petani Mangga Terlibat Dalam Sistem Informal Dengan Pedagang Pengumpul. Sosiohumaniora. 15, (3), 285-293.

Sulistyowati, L. \& Natawidjaja, R. (2016). Commercialization Determinant Of Mango Farmers In West Java-Indonesia. Ijaber, 11, (11), 7537-7557. 